\title{
Sudden Oak Death 1
}

\section{Philip F. Harmon and Carrie L. Harmon ${ }^{2}$}

Sudden oak death is a new disease capable of causing a range of symptoms from leaf spots to plant death on many woody hosts. Because sudden oak death is a new disease, much about the pathogen, host range, and the disease epidemiology is unknown.

\section{Causal Agent and Geographic Distribution}

Sudden oak death is caused by Phytophthora ramorum. The historical origin of the pathogen is unknown, but it was first described in Europe on ornamental Rhododendron sp. and Viburnum sp. in 2001. In 2002 the pathogen was reported in California and Oregon and has since been found in western Canada.

\section{Host Range}

Various symptoms have been produced on more than 40 species of native and cultivated ornamental plants infected with the pathogen (Table 1). The list is not exclusive as many plant species have not yet been tested. It is likely that species closely related to susceptible hosts also could be infected by $P$. ramorum. Additional hosts will be identified as the pathogen is spread to new areas.

\section{Disease Symptoms}

Symptoms of this disease vary from host to host; however, roots of plants infected with $P$. ramorum typically appear healthy. Known hosts and observed symptoms are listed in Table 1. Symptoms may progress rapidly after infection or may not be visible for significant periods of time. Symptom progression is favored by temperatures near $20^{\circ} \mathrm{C}$.

\section{Leaf Lesions}

Leaf lesions typically begin where moisture accumulates on a leaf surface, such as at the leaf tip or petiole (depending on orientation on the plant), along the midvein, or around the margin. Lesions may first appear water-soaked, and a water-soaked margin may be visible on rapidly expanding lesions (Fig. 1). Blighted leaf tissue typically turns tan to brown and may have a reddish tinge (Fig. 2). Lesions commonly expand from the midvein in an angular fashion (Fig.3).

1. This document is PP197, one of a series of the Plant Pathology Department, Florida Cooperative Extension Service, Institute of Food and Agricultural Sciences, University of Florida. Original publication date March 2004. Visit the EDIS Web Site at http://edis.ifas.ufl.edu.

Table 1 and images included in this document were adapted from Davidson, J. M., Werres, S., Garbelotto, M., Hansen, E. M., and Rizzo, D. M. 2003. Sudden oak death and associated diseases caused by Phytophthora ramorum. Online. Plant Health Progress doi:10.1094/PHP-2003-0707-01-DG.

2. Philip F. Harmon, assistant professor, Plant Pathology Department. Carrie Harmon, plant pathology coordinator, Southern Plant Diagnostic Network, Plant Pathology Department, Cooperative Extension Service, Institute of Food and Agricultural Sciences, University of Florida, Gainesville, 32611.

The Institute of Food and Agricultural Sciences (IFAS) is an Equal Employment Opportunity - Affirmative Action Employer authorized to provide research, educational information and other services only to individuals and institutions that function without regard to race, creed, color, religion, age, disability, sex, sexual orientation, marital status, national origin, political opinions or affiliations. For information on obtaining other extension publications, contact your county Cooperative Extension Service office. Florida Cooperative Extension Service / Institute of Food and Agricultural Sciences / University of Florida / Larry R. Arrington, Interim Dean 


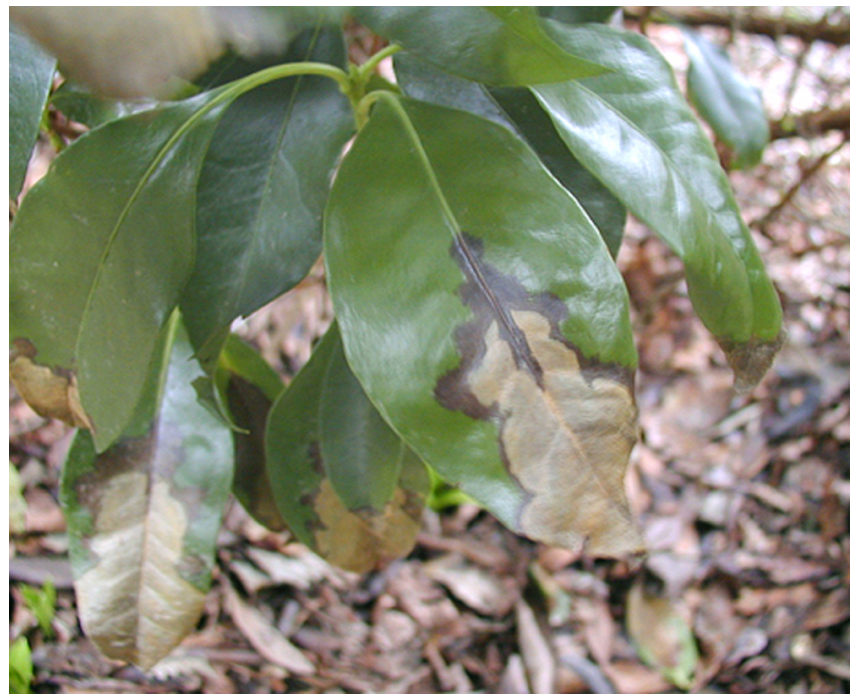

Figure 1. Leaf lesions on Kalmia latifolia (moutain laurel). Note the symptom occurs at the leaf tip, and the lesion has a water-soaked border. Credits: Plant Management Network



Figure 2. Tan to reddish brown leaf lesions typical of sudden oak death on Camellia sp. Credits: Plant Management Network

\section{Bleeding Cankers}

Cankers are sunken or swollen lesions on branches and trunks of woody plants. Cankers may occur beneath the bark and can be difficult to distinguish. Cankers caused by P. ramorum often ooze red sticky sap (Fig. 4). Some bacterial pathogens can cause sap to bleed from cankers, but sap from these cankers has a foul odor. Vascular discoloration is revealed when the bark and outer cambial layer are removed (Fig. 5). Vascular discoloration on mature tan oak is characteristically bright red (Fig. 6).

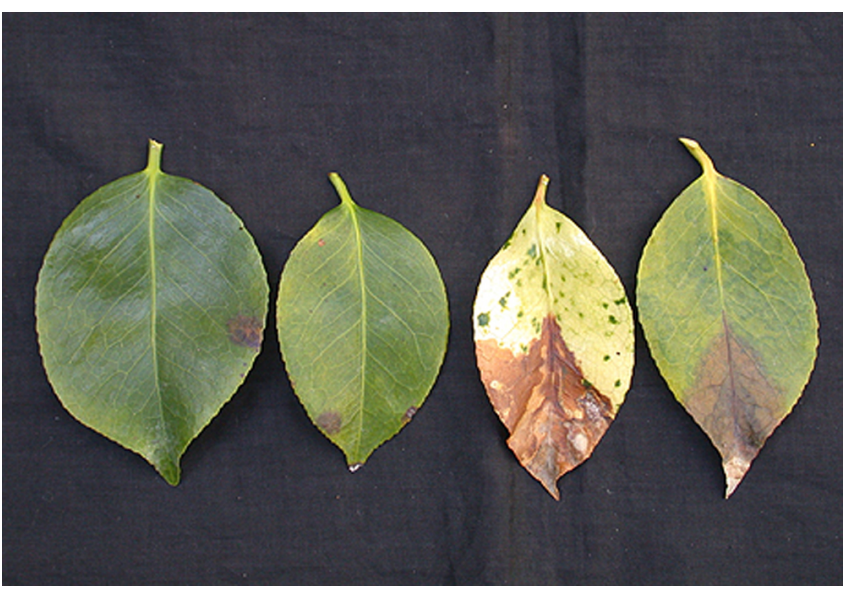

Figure 3. Angular lesions caused by $P$. ramorum on leaves of Camellia sp. Credits: Plant Management Network

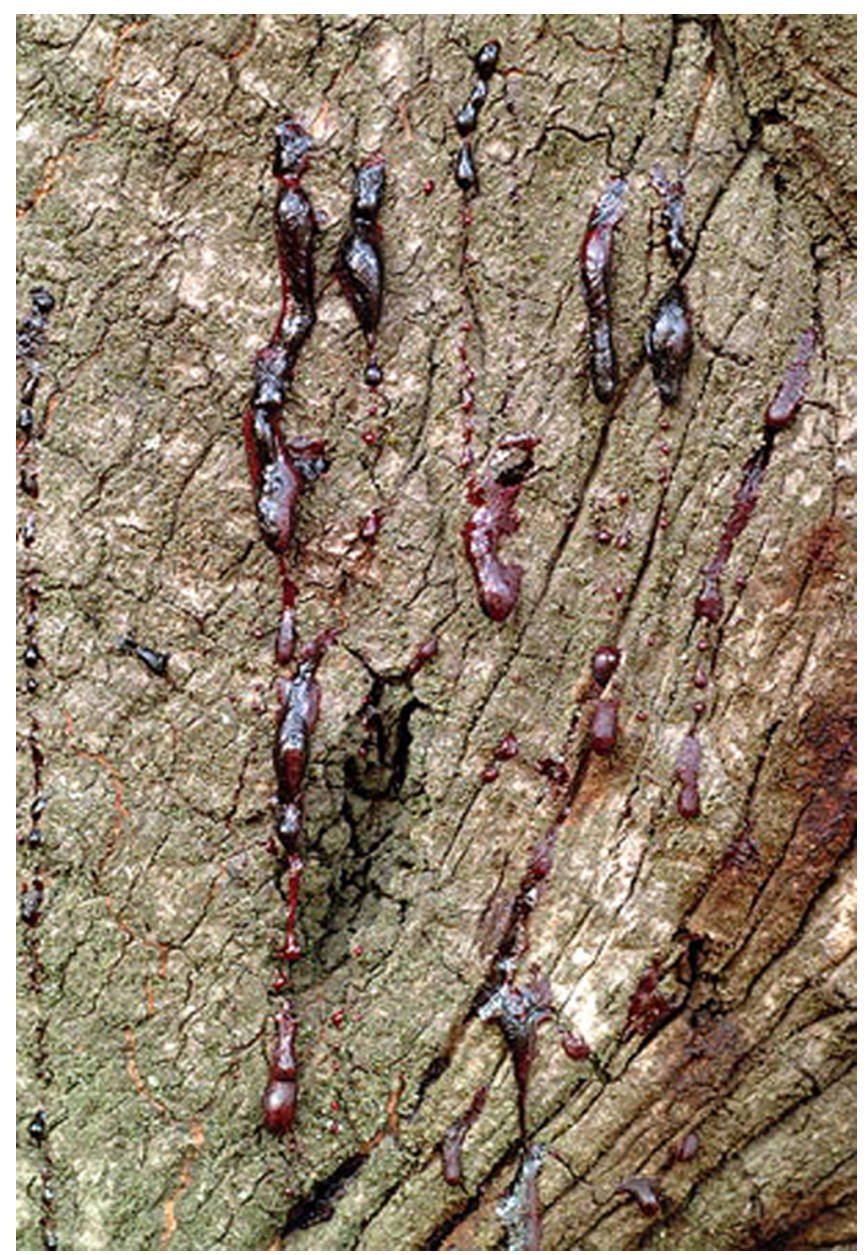

Figure 4. Bleeding canker symptom on coast live oak caused by $P$. ramorum. Credits: Plant Management Network 


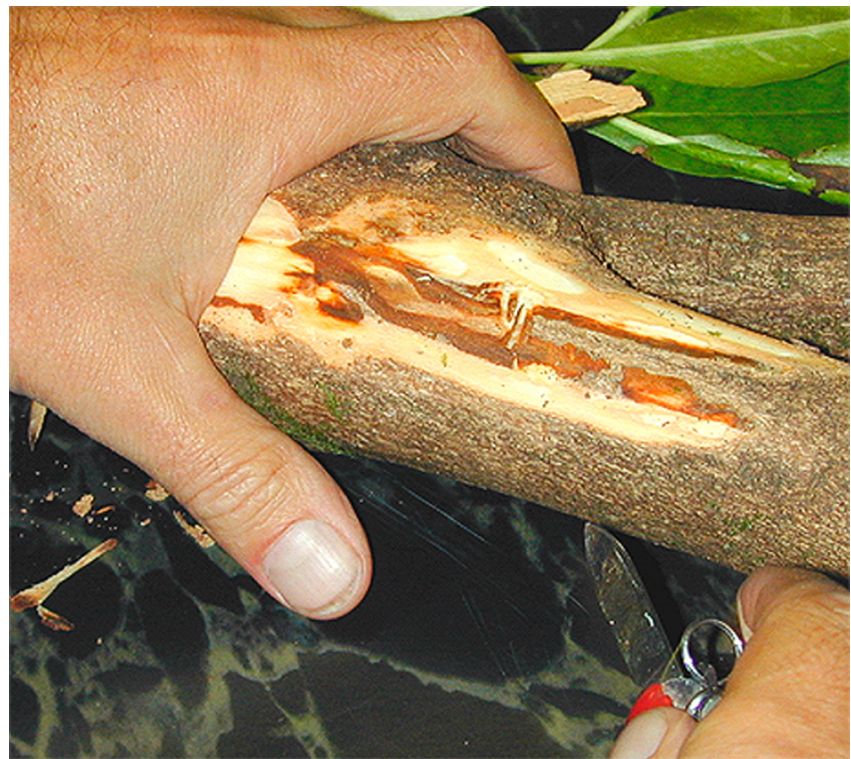

Figure 5. Vascular discoloration of Rhododendron sp. caused by $P$. ramorum. Credits: Plant Management Network

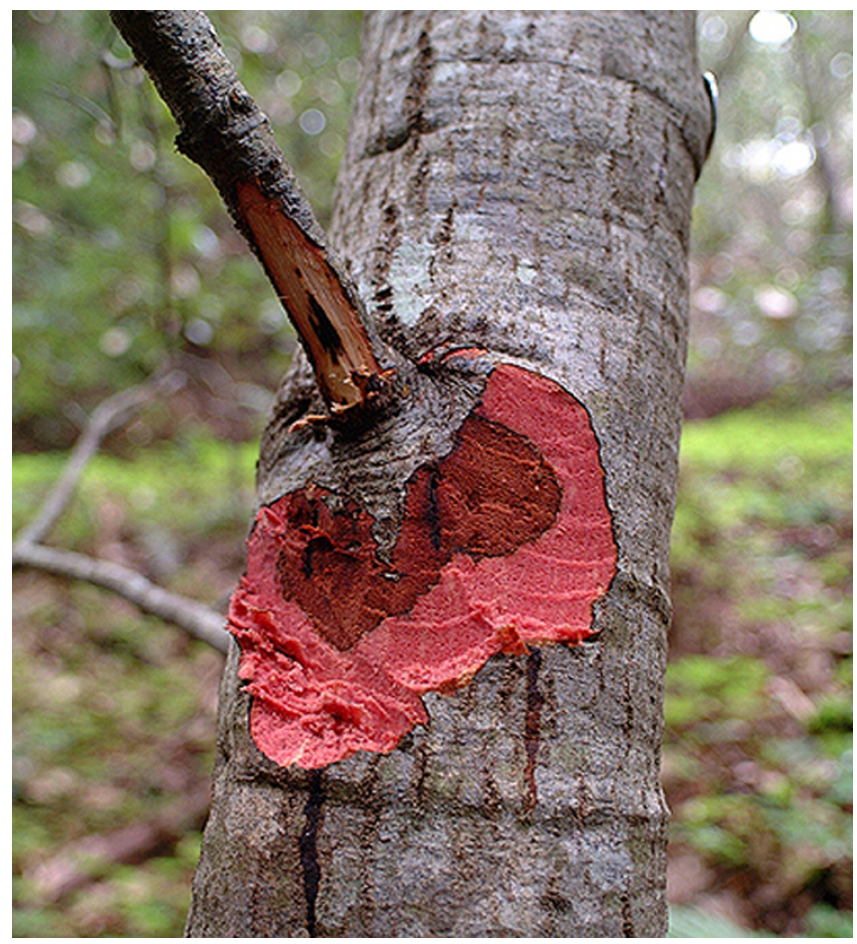

Figure 6. Canker and vascular discoloration on a mature tan oak. Credits: Plant Management Network

\section{Shoot Tip and Stem Blight}

Stem blight often begins at a shoot tip and progresses toward the base of the plant, but infection may occur at any point on a stem and move up or down the plant. Blighted stems appear brown to black and may be killed, resulting in death of attached leaves (Fig. 7). Early symptoms of shoot tip blight may include formation of a "shepherds crook" (Fig. 8).

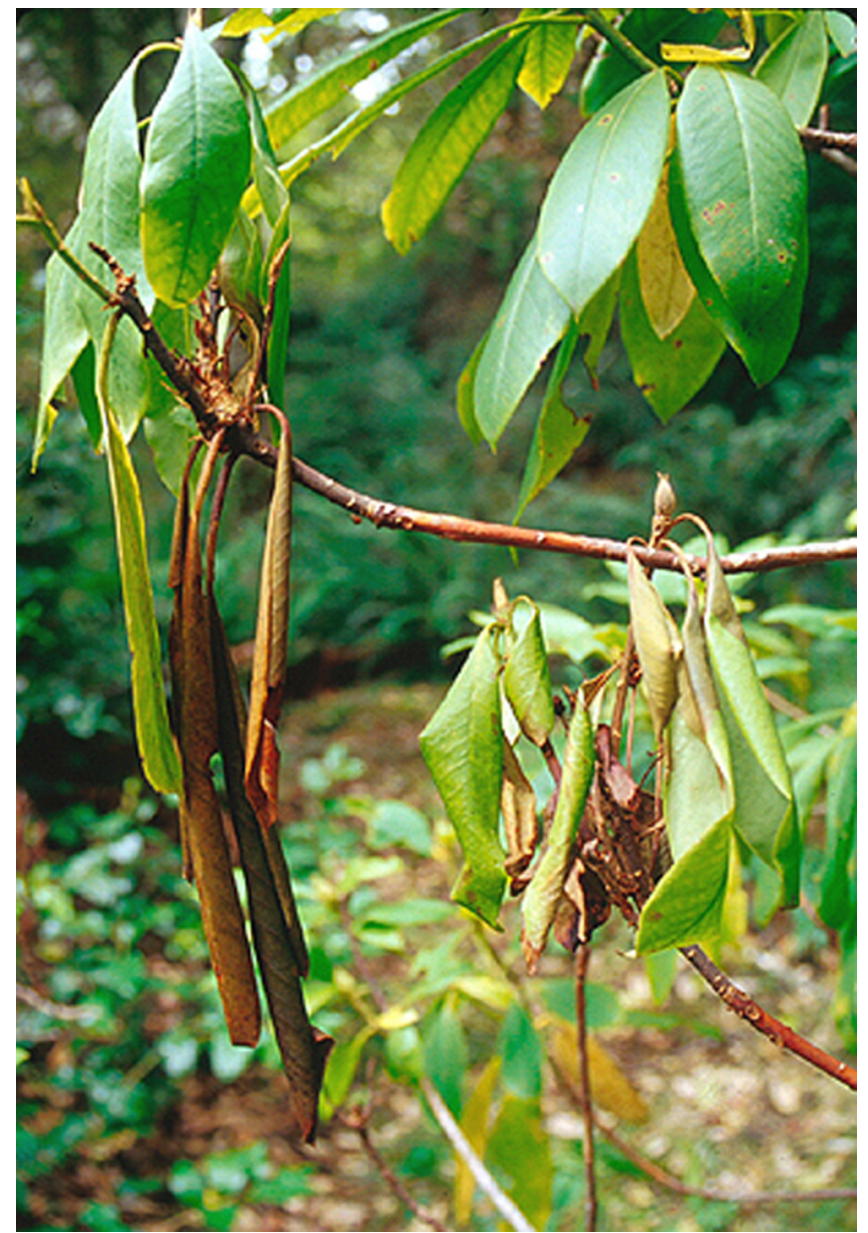

Figure 7. Stem dieback of Rhododendron sp. caused by $P$. ramorum. Credits: Plant Management Network



Figure 8. Shepherds crook symptom on tan oak sapling. Credits: Plant Management Network 


\section{General Wilt}

Viburnum species are among the most susceptible hosts and typically exhibit wilting symptoms that can mimic drought stress. As symptoms progress, individual branches and eventually the entire plant may collapse and die.

\section{Spread of the Pathogen and Control Options}

The fungus can be spread by movement of infected host material, infested soil, irrigation water, and wind-blown rain. Unintentional movement of infected but asymptomatic nursery stock is a potential means of pathogen dissemination. Because this is a new pathogen, the best option for controlling spread of the disease is preventing the introduction and establishment of the pathogen in new areas. Quarantines and eradication programs in conjunction with extensive surveys are the most effective way to deal with potential introductions. Eradication efforts include burning and deep burial of infected plant material.

Fungicides have not been evaluated for management of this disease. It is possible that fungicides that prevent and control diseases caused by other Phytophthora spp. may be effective, but no data are available at this time. 
Table 1. Known hosts, plant part infected, and potential impact of Phytophthora ramorum.

\begin{tabular}{|c|c|c|c|c|}
\hline $\begin{array}{l}\text { Host } \\
\text { species }^{1}\end{array}$ & Family & $\begin{array}{l}\text { Common } \\
\text { name }\end{array}$ & Location $^{2}$ & Plant part infected and impact \\
\hline $\begin{array}{l}\text { Acer } \\
\text { macrophyllum }\end{array}$ & Aceraceae & Big leaf maple & $\mathrm{CA}$ & foliar lesions; long term impact unknown \\
\hline $\begin{array}{l}\text { Toxicodendron } \\
\text { diversilobum }\end{array}$ & Anacardiaceae & Poison oak & $\mathrm{CA}, \mathrm{OR}$ & Limited stem canker; long term impact unknown \\
\hline $\begin{array}{l}\text { Lonicera } \\
\text { hispidula }\end{array}$ & Caprifoliaceae & Honeysuckle & $\mathrm{CA}$ & foliar lesions; long term impact unknown \\
\hline Viburnum spp. ${ }^{3}$ & Caprifoliaceae & Viburnum & CA, OR, E & Stem lesions \\
\hline $\begin{array}{l}\text { Arbutus } \\
\text { menziesii }\end{array}$ & Ericaceae & Madrone & $\mathrm{CA}$ & $\begin{array}{l}\text { branch cankers, foliar lesions; death of } \\
\text { regeneration and possibly large trees }\end{array}$ \\
\hline $\begin{array}{l}\text { Arctostaphylos } \\
\text { manzanita }\end{array}$ & Ericaceae & Manzanita & $\mathrm{CA}$ & $\begin{array}{l}\text { stem and branch cankers, foliar lesions; dieback } \\
\text { of branches }\end{array}$ \\
\hline Kalmia latifolia & Ericaceae & $\begin{array}{l}\text { Mountain } \\
\text { laurel }\end{array}$ & $\mathrm{E}$ & foliar lesions; long term impact unknown \\
\hline Pieris spp. ${ }^{4}$ & Ericaceae & Andromeda & CA, OR, E & $\begin{array}{l}\text { stem cankers and foliar lesions; long term impact } \\
\text { unknown }\end{array}$ \\
\hline $\begin{array}{l}\text { Rhododendron } \\
\text { spp. }^{5}\end{array}$ & Ericaceae & $\begin{array}{l}\text { Ornamental } \\
\text { rhododendron }\end{array}$ & $\mathrm{CA}, \mathrm{OR}, \mathrm{E}$ & $\begin{array}{l}\text { stem and branch cankers, foliar lesions; dieback } \\
\text { and death of plants }\end{array}$ \\
\hline $\begin{array}{l}\text { Vaccinium } \\
\text { ovatum }\end{array}$ & Ericaceae & $\begin{array}{l}\text { Evergreen } \\
\text { huckleberry }\end{array}$ & $\mathrm{CA}, \mathrm{OR}$ & $\begin{array}{l}\text { stem and branch cankers, foliar lesions; dieback } \\
\text { of canes and possible death of plants }\end{array}$ \\
\hline $\begin{array}{l}\text { Lithocarpus } \\
\text { densiflora }\end{array}$ & Fagaceae & Tanoak & $\mathrm{CA}, \mathrm{OR}$ & $\begin{array}{l}\text { stem and branch cankers, foliar lesions; death of } \\
\text { large trees, saplings and regeneration }\end{array}$ \\
\hline Q. chrysolepsis & Fagaceae & $\begin{array}{l}\text { Canyon live } \\
\text { oak }\end{array}$ & $\mathrm{CA}$ & $\begin{array}{l}\text { Stem cankers, death of saplings, possible death } \\
\text { of large trees }\end{array}$ \\
\hline Q. kellogii & Fagaceae & $\begin{array}{l}\text { California } \\
\text { Black } \\
\text { oak }\end{array}$ & $\mathrm{CA}$ & stem cankers; death of large trees \\
\hline $\begin{array}{l}\text { Q. parvula var. } \\
\text { shrevei }\end{array}$ & Fagaceae & Shreves oak & $\mathrm{CA}$ & stem cankers; death of large trees \\
\hline $\begin{array}{l}\text { Quercus } \\
\text { agrifolia }\end{array}$ & Fagaceae & Coast live oak & $\mathrm{CA}$ & stem cankers; death of large trees \\
\hline $\begin{array}{l}\text { Aesculus } \\
\text { californica }\end{array}$ & $\begin{array}{l}\text { Hippocastan } \\
\text {-aceae }\end{array}$ & $\begin{array}{l}\text { California } \\
\text { buckeye }\end{array}$ & $\mathrm{CA}$ & foliar lesions; long term impact unknown \\
\hline $\begin{array}{l}\text { Umbellularia } \\
\text { californica }\end{array}$ & Lauraceae & $\begin{array}{l}\text { Bay laurel, } \\
\text { Oregon }\end{array}$ & $\mathrm{CA}$ & foliar lesions; long term impact unknown \\
\hline $\begin{array}{l}\text { Pseudotsuga } \\
\text { menziesii }\end{array}$ & Pinaceae & Douglas-fir & $\mathrm{CA}$ & $\begin{array}{l}\text { branch cankers, foliar lesions; death of new } \\
\text { shoots and small branches }\end{array}$ \\
\hline $\begin{array}{l}\text { Rhamnus } \\
\text { californica }\end{array}$ & Rhamnaceae & Coffeeberry & $\mathrm{CA}$ & foliar lesions; long term impact unknown \\
\hline $\begin{array}{l}\text { Rhamnus } \\
\text { purshiana }\end{array}$ & Rhamnaceae & Cascara & OR & foliar lesions; long term impact unknown \\
\hline $\begin{array}{l}\text { Heteromeles } \\
\text { arbutifolia }\end{array}$ & Rosaceae & Toyon & $\mathrm{CA}$ & $\begin{array}{l}\text { branch cankers, foliar lesions; branch dieback, } \\
\text { long term impact unknown }\end{array}$ \\
\hline
\end{tabular}


Table 1. Known hosts, plant part infected, and potential impact of Phytophthora ramorum.

\begin{tabular}{|c|c|c|c|c|}
\hline $\begin{array}{l}\text { Host } \\
\text { species }^{1}\end{array}$ & Family & $\begin{array}{l}\text { Common } \\
\text { name }\end{array}$ & Location $^{2}$ & Plant part infected and impact \\
\hline $\begin{array}{l}\text { Rubus } \\
\text { spectabilis }\end{array}$ & Rosaceae & Salmon berry & OR & $\begin{array}{l}\text { Foliar lesions; long term impact unknown (Kochs } \\
\text { Postulates in progress) }\end{array}$ \\
\hline $\begin{array}{l}\text { Sequoia } \\
\text { sempervirens }\end{array}$ & Taxodiaceae & $\begin{array}{l}\text { Coast } \\
\text { redwood }\end{array}$ & $\mathrm{CA}$ & $\begin{array}{l}\text { branch cankers, foliar lesions; death of sprouts, } \\
\text { decline of saplings }\end{array}$ \\
\hline Camellia spp. ${ }^{6}$ & Theaceae & Camellia & $\mathrm{CA}, \mathrm{E}$ & Leaf lesions; long term impact unknown \\
\hline \multicolumn{5}{|c|}{$\begin{array}{l}1 \text { Cultures of } P \text {. ramorum have been obtained from all hosts with the exception of } A \text {. manzanita. } \\
2 \text { Location from which } P \text {. ramorum has been observed on named host to date. CA, California; OR, Oregon; E, Europe. } \\
3 \text { Viburnum species from which } P \text {. ramorum has been recovered include: V. bodnantense, V. fragans, V. plicatum, and V. } \\
\text { tinus. } \\
4 \text { Pieris species and cultivars infected by } P \text {. ramorum include: } P \text {. formosa var. forrestii and } P \text {. japonica. } \\
5 \text { Rhododendron species and cultivars from which } P \text {. ramorum has been isolated include: Rhododendron catawbiense, } R \text {. } \\
\text { macrophyllum, Catawbiense Grandiflorum, Catawbiense Boursalt, Schneewolk, Colonel Coen, Gomer Waterer, and } \\
\text { Cunninghams White. } \\
6 \text { Camellia species and cultivars from which } P \text {. ramorum has been isolated include: Camellia japonica (Kramers Supreme, } \\
\text { Kumasaka, Mrs. Charles Cobb, and Silver Waves); and Camellia sasanqua (Bonanza). }\end{array}$} \\
\hline
\end{tabular}

